\title{
The effect of increasing plant population on maize silage yield and quality
}

\author{
R. J. DENSLEY, R.J. BRENTON-RULE, G.M. AUSTIN, D.W. DENSLEY and R. TSIMBA \\ Genetic Technologies Ltd, P.O. Box 105 303, Auckland \\ rbrenton-rule@genetic.co.nz
}

\begin{abstract}
For the past decade maize silage has been planted at 100000 plants/ha in New Zealand. Modern maize silage hybrids have enhanced stress tolerance making them more adaptable to higher plant populations. This study examined the effect of a range of established plant populations $(85000$ $100000,115000,130000$ and 145000 plants/ha) on the yield and quality of 12 Pioneer $^{\circledR}$ brand maize silage hybrids grown at 13 locations over two seasons. As plant population increased maize silage dry matter (DM) yield increased significantly $(\mathrm{P}<0.01)$ from 18.66 to $20.52 \mathrm{t} \mathrm{DM} /$ ha (Year 1) and from 22.10 to $23.69 \mathrm{t} \mathrm{DM} /$ ha (Year 2). Location $\mathrm{x}$ hybrid interaction was significant $(\mathrm{P}<0.01)$ for total DM yield and DM percentage. Hybrid $\mathrm{x}$ population and location $\mathrm{x}$ population $\mathrm{x}$ hybrid interactions were not significant. There was a significant effect of population and location $\mathrm{x}$ population on crude protein (Year 2) with the highest population plots having slightly lower crude protein percentages. The effects of population, location $\mathrm{x}$ population on all other nutritional quality parameters were not significant. Even when the cost of additional seed and seed insecticide treatment is considered, lifting established populations to 115000 to 130000 plants/ha is profitable for dairy farmers growing and feeding maize silage.
\end{abstract}

Keywords: maize silage, plant population, supplementary feed

\section{Introduction}

An increasing number of New Zealand dairy farmers are using maize silage, with the quantity used per farm rising (Kolver et al. 2001). For dairy farmers, the return for incorporating maize silage into their farm system is largely determined by the cost per kilogram of maize silage dry matter (DM) and the response in milksolids production. Recent research has shown that there are significant differences in quality parameters between maize silage hybrids but that hybrid quality has a much lower impact on milk production than hybrid yield (Kolver et al. 2003).

Most of the costs associated with growing and harvesting maize silage are fixed. Therefore the crop yield is the single variable that has the largest impact on maize silage cost. Assuming growing costs of
$\$ 1878 /$ ha, a $1 \mathrm{t} \mathrm{DM} /$ ha increase in yield will decrease DM cost by up to $0.5 \mathrm{c} / \mathrm{kg}$. Significant improvements in the genetic yield potential of maize hybrids have occurred in the last 70 years. The biological maximum for maize grain yield was calculated to be $31.5 \mathrm{t} / \mathrm{ha}$ (Tollenaar 1985). This translates to a maize silage yield of approximately $56.7 \mathrm{t} \mathrm{DM} /$ ha and is equivalent to the actual yield achieved by Francis Childs, winner of the 2002 USA National Corn Growers Association Contest (Zinkand 2002). Trials conducted on New Zealand farms from Northland to Canterbury in 1996-2001 show current average maize silage yields in the range 20-25 t DM/ha (Densley et al. 2001). The highest yield recorded in Pioneer ${ }^{\mathbb{B}}$ brand maize silage trials in New Zealand was $34.5 \mathrm{t} \mathrm{DM} /$ ha recorded in a Pioneer ${ }^{\mathbb{B}}$ brand 33 G26 crop in the Bay of Plenty.

Yield gains have resulted from improved hybrid genetics and better agronomic practices such as soil fertility and weed control. Among these factors, genetic improvement of maize hybrids for superior stress tolerance has likely contributed the most to increased yields. A key result of enhanced stress tolerance is the adoption of higher plant populations (Paszkiewicz et al. 2001)

For the past decade, the recommended maize silage planting population in New Zealand has been around 100000 plants per hectare and most growers are planting at this level. Thom et al. (1981), showed that increasing planting population from 85000 to 362000 plants/ha increased machine harvest estimated maize silage yield by $2.2 \mathrm{t} \mathrm{DM} /$ ha (Year 1 ) and $3.0 \mathrm{t} \mathrm{DM} / \mathrm{ha}$ (Year 2). In the USA, increasing plant population from 44500 to 104500 plants/ha increased drymatter yield by 1.7 to $4.1 \mathrm{t} \mathrm{DM} / \mathrm{ha}$ depending on location (Cusicanqui et al. 1999).

The objectives of this paper were to quantify the effect of maize silage plant population on DM yield and quality and determine optimum planting populations for a range of commercial maize silage hybrids in New Zealand.

\section{Materials and methods \\ Field testing}

A range of Pioneer ${ }^{\circledR}$ brand maize silage hybrids were precision planted in $76.2 \mathrm{~cm}$ rows at 3 locations during Spring 2001 (Year 1) and 10 locations during 
Spring 2002 (Year 2). Locations ranged from Waikato to Canterbury. The 12 Pioneer ${ }^{\circledR}$ brand maize silage hybrids ranged from 75 to 112 silage comparative relative maturity (CRM) and only those hybrids which would be used commercially in an area were included in the population trials for that area. The planting population was 160000 plants/ha.

Planting populations and hybrids were allocated to plots using a split plot arrangement in a randomised complete block design. There were a total of 3 replicates per treatment and the plot size was 4 rows wide x $5.3 \mathrm{~m}$ long. Starter fertiliser (12-10-10) was applied at $300 \mathrm{~kg} / \mathrm{ha}$ and the plots were side-dressed with $400 \mathrm{~kg} / \mathrm{ha}$ urea after thinning. Weeds were controlled using Roustabout, Stomp and Gardoprim herbicides at recommended rates.

Plots were hand thinned when the plants were at about the V4 ( $4^{\text {th }}$ collared leaf) stage. The target populations were $85000,100000,115000$ and 130000 plants/ha in Year 1 and 100000, 115000, 130000 and 145000 plants/ha in Year 2. Early seedling death due to cutworm and bird damage meant that at thinning time, the stand population was less than ideal at some of the locations in Year 2. For these locations thinning population levels of 85000 , 100000, 115000 and 130000 plants/ha were used.

\section{Yield measurements}

Silage harvest took place when the hybrids were visually assessed to be between $30-35 \%$ whole plant DM. Plots were assessed for harvest population and stalk and root lodging. The centre two rows of each plot were hand harvested and weighed. A $1 \mathrm{~kg}$ sample of chopped whole plant maize was collected and dried at $62^{\circ} \mathrm{C}$ until constant weight. Dry, ground samples were analysed by near-infrared spectroscopy.

\section{Sample analysis}

Yield was determined for each replicate plot. Each sample from each replicate plot was analysed for DM, nitrogen-free extract (NFE), starch, acid detergent fibre (ADF), neutral detergent fibre (NDF) and in vitro digestibility in Year 1 and for soluble sugars, starch, acid detergent fibre (ADF), neutral detergent fibre (NDF), crude protein (CP) and in vitro digestibility in Year 2.

\section{Data analysis}

The Generalised Linear Model Procedure in SAS was used to detect interactions. A quadratic model was used to predict optimum plant density where adequate population levels existed to make this determination between yield comparisons.

\section{Results}

\section{Year 1}

Maize silage DM yield and \% DM varied significantly $(\mathrm{P}<0.01)$ between locations (Table 1$)$. The average trial yield range was $12.98 \mathrm{t} \mathrm{DM} /$ ha at Arohena (West Waikato) to $25.04 \mathrm{t} \mathrm{DM} / \mathrm{ha}$ at Walton (East Waikato). As plant population increased, there was a significant $(\mathrm{P}<0.01)$ increase in maize silage DM yield (Table 1 ) but not in \% DM. Location $\mathrm{x}$ hybrid interaction was






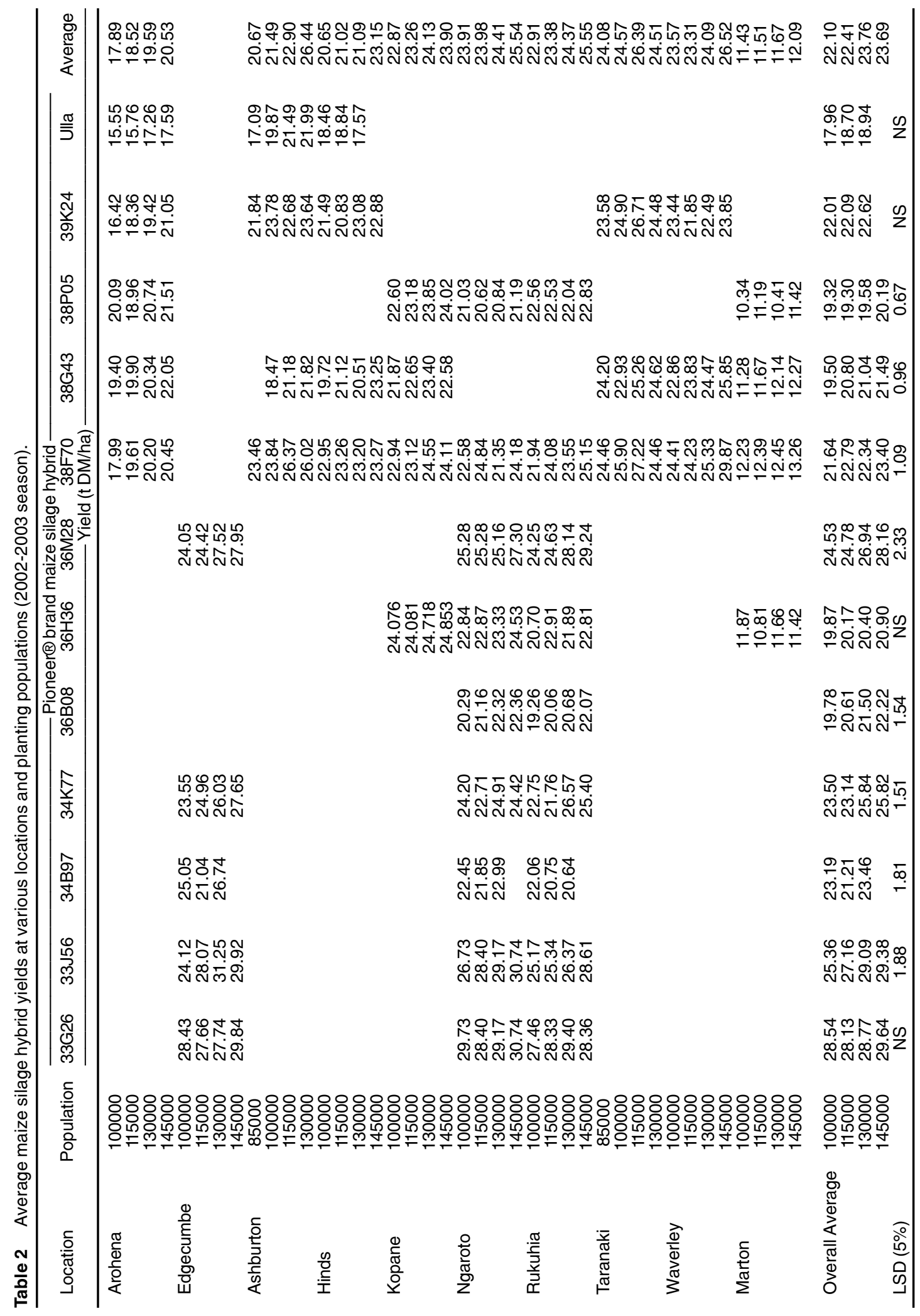

File identification only -15 
significant $(\mathrm{P}<0.01)$ for total $\mathrm{DM}$ yield and \%DM. Hybrid $\mathrm{x}$ population and location $\mathrm{x}$ population $\mathrm{x}$ hybrid interactions were not significant.

The occurrence of stalk lodging was minimal at all three sites $(<1 \%)$. Root lodging was observed at the Arohena location (13\%) but there was no significant interaction between root lodging and plant population.

There was a significant difference $(\mathrm{P}<0.01)$ in the nitrogen-free extract, starch percentage, ADF, NDF and in vitro digestibility of whole plant maize samples collected from different locations. The effects of population, location $\mathrm{x}$ population and location $\mathrm{x}$ population $\mathrm{x}$ hybrid on nutritional quality parameters were not significant.

\section{Year 2}

Maize silage DM yield and \% DM varied significantly $(\mathrm{P}<0.01)$ betw een locations (Table 2$)$. The yield range was $11.68 \mathrm{t} \mathrm{DM} / \mathrm{ha}$ at Marton to $26.68 \mathrm{t} \mathrm{DM} / \mathrm{ha}$ at Edgecumbe. As plant population increased, there was a significant $(\mathrm{P}<0.01)$ increase in maize silage DM yield (Table 2) but not in \%DM. Location $x$ hybrid interaction was significant $(\mathrm{P}<0.01)$ for total DM yield and \%DM. Hybrid $\mathrm{x}$ population interaction was significant for DM yield but not \% DM. The threeway location $\mathrm{x}$ population $\mathrm{x}$ hybrid interaction was not significant for yield or \% DM.

The occurrence of stalk lodging was minimal at all sites $(<1 \%)$. Root lodging was observed at the Arohena (9\%), Ngaroto (10\%) and Rukuhia (12\%) locations but there was no significant interaction between root lodging and plant population.

There was a significant difference $(\mathrm{P}<0.01)$ in the soluble sugar, starch percentage, $\mathrm{ADF}, \mathrm{NDF}, \mathrm{CP}$ and in vitro digestibility of whole plant maize samples collected from different locations. The effects of population and location $\mathrm{x}$ population were significant for $\mathrm{CP}(\mathrm{P}<0.01)$ but no other nutritional parameters. The highest population had an average crude protein $0.29 \%$ lower than the lowest population. The location $\mathrm{x}$ population $\mathrm{x}$ hybrid effect on all nutritional quality parameters was not significant.

\section{Discussion}

Over the past 30 years Pioneer plant breeders have focused on yield stability across a range of environments, increased root and stalk strength and increased resistance to high plant population stress. Researchers have observed that modern corn hybrids have a higher leaf area index which allows the plant to intercept more light, higher rates of leaf photosynthesis and higher radiation use efficiency during grain filling (Paszkiewicz et al. 2001).
Higher plant populations increase competition among individual plants for water, sunlight and soil nutrients. This may lower individual plant yield but increases yield/ha. This study showed that increasing maize silage hybrid population from 85000 plants/ ha to 145000 plants/ha significantly increased maize silage yield with no effect on harvest drymatter percentage or root and stalk lodging. Increasing population from 100000 to 130000 plants/ha lifted drymatter yield by $0.65 \mathrm{t} \mathrm{DM} / \mathrm{ha}(3.3 \%)$ in Year 1 and $1.59 \mathrm{t} \mathrm{DM} / \mathrm{ha}(7.2 \%)$ in Year 2. While overseas maize grain yield research shows that the response to plant population is affected by the yield level of the growing environment (P aszkiewicz et al. 2001), there was no interaction between plant population response and location in this study. Even at Marton where DM yield was low (11- $13 \mathrm{t} \mathrm{DM/ha)} \mathrm{due} \mathrm{to} \mathrm{moisture} \mathrm{stress,}$ most hybrids showed a yield response to increasing plant population. However, in low yield environments (e.g. low moisture and/or fertility) where the total silage yield response to increasing population is small, economics of increasing plant population should be carefully examined.

There was a significant hybrid $\mathrm{x}$ population interaction in Year 2 indicating that hybrids responded differently to population levels. Agronomic optimum populations could not be determined for most hybrids as the population levels tested were not high enough to reach a yield plateau. These hybrids appeared to have optimum plant populations for silage of more than 130000 plants/ha. Using the two year average data, the optimum planting populations for Pioneer ${ }^{\circledR}$ brand $38 \mathrm{G} 43,38 \mathrm{~F} 70$ and $36 \mathrm{H} 36$ were 119400 , 119300 and 116400 plants/ha respectively.

Increasing maize silage planting population had no effect on nutritional parameters with the exception of crude protein (Year 2). As silage plant population increased, generally yield increased and crude protein decreased from 7.44 to $7.15 \%$. Maize silage is generally used as an energy source to supplement high protein pastures therefore the impact of the lower crude protein will be negligible for most farmers.

From this data it appears that the standard planting population of 100000 plants/ha is too low. Silage growers could achieve higher yields without sacrificing crop standability or silage nutritional quality by increasing planting populations. While exact population recommendations for optimum yield should be hybrid specific, it appears that harvest populations of 115000 to 130000 plants/ha should be considered by most growers.

In this study, plants were thinned to target populations at the V4 stage. Plant loss between the V4 stage and silage harvest was negligible. Growers 
targeting harvest populations of 115000 to 130000 plants/ha should consider seed germination and vigour as well as likely plant loss due to bird and insect damage when determining planting rates.

The determination of cost versus benefit is a critical factor in plant population decisions. Increased yields with higher populations must be weighed against additional seed and seed insecticide costs to determine optimum plant density.

For economic analysis, the financial implications of planting Pioneer ${ }^{\circledR}$ brand 33 G26 (CRM 112) and 36M28 (CRM 103) at 100000 and 130000 plants/ha were considered. Milk production response was assumed to be $100 \mathrm{~g}$ milksolids (MS) $/ \mathrm{kg}$ DM. Milk price was $\$ 3.60 / \mathrm{kg}$ MS, maize seed price and seed insecticide treatment $\$ 260$ and $\$ 103$ respectively per 80000 kernel bag. The average lift in yield by increasing plant population from 100000 to 130000 plants/ha was $0.92 \mathrm{t} \mathrm{DM} / \mathrm{ha}$ and $1.95 \mathrm{t} \mathrm{DM} /$ ha for $33 \mathrm{G} 26$ and 36M28 respectively. The per hectare increase in milk income was \$340.99 and \$720.64 for $33 \mathrm{G} 26$ and 36M28 respectively. Additional seed and seed insecticide treatment price was $\$ 136.13 /$ ha. The net return was $\$ 204.87 /$ ha for $33 \mathrm{G} 26$ and $\$ 584.51 /$ ha for $36 \mathrm{M} 28$.

To ensure that the maximum yield potential of maize silage crops are realised, growers must ensure that fertiliser application rates exceed the nutrient demand of crops. As maize silage yields increase, growers will have to alter their nutrient applications accordingly however currently most growers are fertilising for higher yields than they are actually achieving.

Higher yielding crops take longer to harvest. Currently most harvesting contractors charge on a per hectare basis so there is no additional cost to the grower of a higher yielding crop. Stacking, covering and silage inoculant costs are increased for higher yielding crops. These costs have not been considered in this economic analysis.

\section{Conclusion}

1. This New Zealand research has shown that current recommended maize silage planting populations of 100000 plants/ha are too low for modern Pioneer ${ }^{\circledR}$ brand maize silage hybrids and yield increases of up to $7.5 \%$ could be achieved if harvested populations were lifted to around 115000 to 130000 plants/ha. On average, even when the cost of the additional seed and seed insecticide treatment is taken into consideration, increasing planting rate increases dairy farm profit.

2. Lifting maize silage plant population has no detrimental affect on root or stalk lodging or maize silage quality parameters.

3. Planting populations will be hybrid and environment specific and will be determined by the likely target harvest population, seed germination and vigour and the likely plant loss due to birds and insect pests.

4. To attain the maximum potential benefit from increased maize silage plant populations, growers must ensure that fertiliser applications exceed the nutrient requirements of high yielding crops.

\section{ACKNOWLEDGEMENTS}

The authors would like to thank the Pioneer field technicians who provided substantial technical assistance and Tammiraj Iragavarapu and Brian Meese (Pioneer Hi-Bred International) for statistical analysis

\section{REFERENCES}

Cusicanqui, J. A; Lauer, J.C. 1999. Plant density and hybrid influence on corn silage yield and quality. American Society of Agronomy Journal 91: 911915.

Densley, R.; Miller, D.; Kolver, E.S. 2001. Breaking the feed barrier using maize silage. Proceedings of the New Zealand Grassland Association 63: 289293.

Kolver, E.S.; Densley, R.; Miller D.; Williams, I.; Sapienza D. 2003. Ranking maize hybrids for silage quality and milk production in pasturebased dairying. Proceedings of the New Zealand Society of Animal Production 63: 101-106.

Kolver, E.S.; Roche, J.R.; Miller, D.; Densley, R. 2001. Maize silage for dairy cows. Proceedings of the New Zealand Grassland Association 63: 195201.

Paszkiewicz, S.; Butzen, S. 2001. Corn Hybrid Reponses to Plant Population. Pioneer Crop Insights Volume 11. No 6. Pioneer Hi-Bred International Inc., Johnston, Iowa.

Tollenaar, M. 1985. What is the current upper limit of corn productivity? In: Proceedings of the Conference on Physiology, Biochemistry and Chemistry Associated with Maximum Yield Corn. Foundation for Agronomic Research and Potash Phosphate Institute, St Louis, Missouri.

Thom, E.R.; Dorofaeff, F.D.; Dyson, C.B. 1981. Effect of plant population and time of harvest on yield and quality of maize (Zeal mays L.) grown for silage. New Zealand Journal of Agricultural Research 24: 285-292.

Zinkand, D. 2002. Childs keeps his crown. pp. 20. In: Iowa Farmer Today. December $28^{\text {th }}$. 